\title{
Laparoscopic excision of caesarean scar ectopic pregnancy
}

\author{
B R G D N K Biyagama ${ }^{1}$, A Fernandoํㅜㄴ, K C D P Silva ${ }^{1}$, M Kobalakrishnan ${ }^{1}$, U N Wijenayake ${ }^{2}$
}

Ceylon Medical Journal 2015; 60: 111-112

\section{Introduction}

Caesarean scar pregnancy is one of the rarest forms of ectopic pregnancy where implantation occurs in the previous caesarean scar [1]. Due to the rarity of the condition, no evidence based treatment option is available for this condition at present. We report a case of laparoscopic management of a caesarean scar ectopic pregnancy.

\section{Case}

A 36-year-old female who had a emergency caesarean section 7 years ago due to fetal distress, this time presented to the clinic for the dating scan. Transvaginal ultrasound showed a gestational sac of $21 \mathrm{~mm}$ size with a fetal pole over the previous caesarean scar and there were no free fluid in the peritoneal cavity. Patient was clinically asymptomatic on presentation.

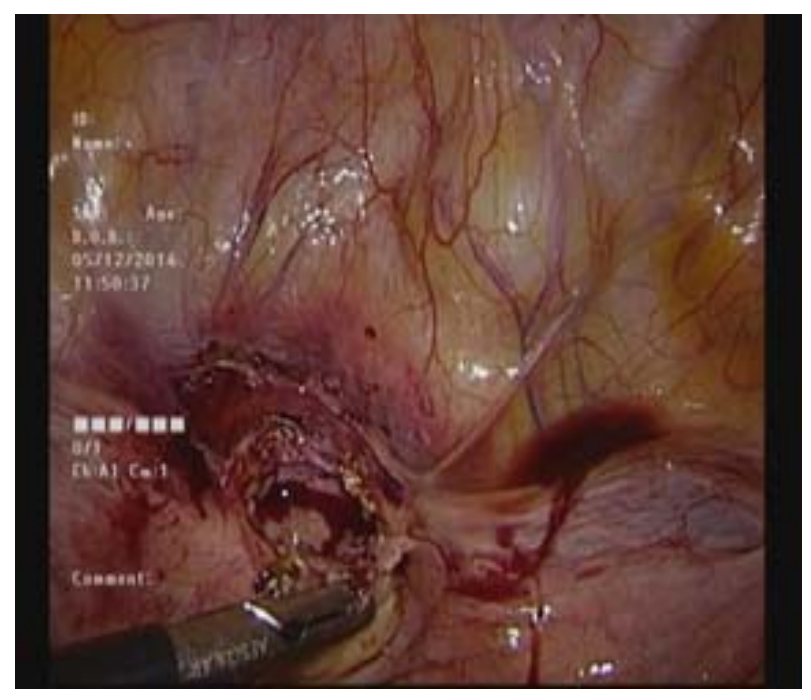

Figure 1. Exposing the ectopic site.

She underwent a laparoscopic excision of scar ectopic pregnancy under general anaesthesia. Vasopressin $20 \mathrm{U}$ in $200 \mathrm{ml}$ of normal saline was injected to the uterus. Bladder was pushed down and ectopic site was exposed. Resection of the ectopic tissue with a segment of myometrium was done using monopolar diathermy. Defect was reconstructed using 'Barbed' sutures. Surgery was uncomplicated and estimated blood loss was $50 \mathrm{ml}$. Histopathology report concluded the specimen to be compatible with an abnormal implantation of conception at caesarean scar site.

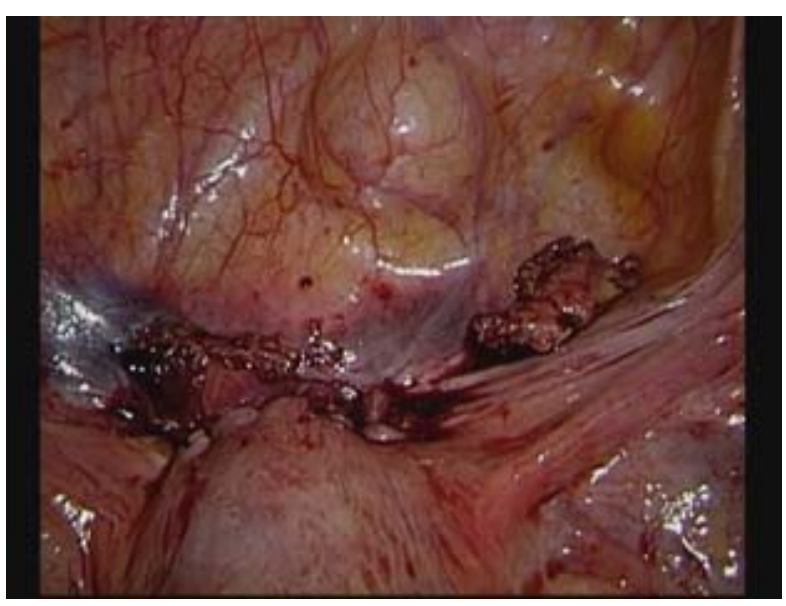

Figure 2. After reconstruction.

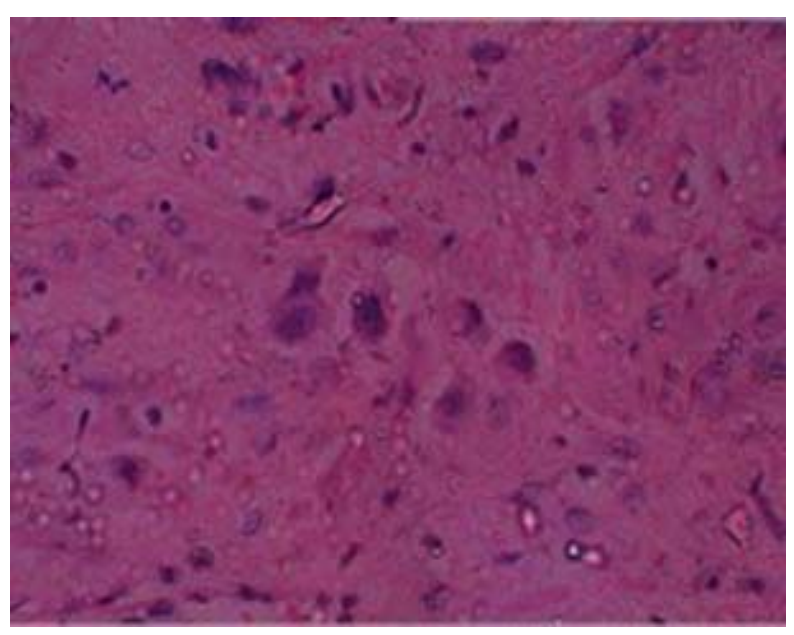

Figure 3. Trophoblastic tissue with scar tissue.

${ }^{1}$ Colombo South Teaching Hospital, Kalubowila and ${ }^{2}$ University of Sri Jayewardenepura, Sri Lanka.

Correspondence: BRGDNKB, e-mail: <dineshbiyagama@hotmail.com>. Received 24 April and revised version accepted 25 July 2015. 


\section{Discussion}

Caesarean scar pregnancy is a rare but potentially life threatening complication, which can be associated with severe maternal morbidity and mortality [2,6,7].

Currently most of the caesarean scar ectopic pregnancies are managed by laparotomy. However, in haemodynamically stable patients, laparoscopy is an effective treatment option [3]. This treatment modality is associated with less morbidity. The operating time and intraoperative blood loss is lower than an open surgical approach [4]. Furthermore, laparoscopy is associated with shorter hospital stay and less analgesic requirements postoperatively. Postoperative adhesion formation is also less with laparoscopy. However, this treatment modality requires laparoscopic facilities and clinical expertise [5]. The main challenge while performing laparoscopic resection is torrential bleeding which can be minimised by injection of vasopressin into the uterus.

\section{Conflicts of interests}

There are no conflicts of interest.

\section{References}

1. Herman A, Weinraub Z, Avrech O, Maymon R, Ron-El R, Bukovsky Y. Follow up and outcome of isthmic pregnancy located in a previous caesarean section scar. Br J Obstet Gynaecol 1995; 102: 839-41.

2. Godin PA, Bassil S, Donnez J. An ectopic pregnancy developing in a previous cesarean section scar. Fertil Steril 1997; 67: 398-400.

3. Seow KM, Cheng WC, Chuang J, et al. Methotrexate for cesarean scar pregnancy after in vitro fertilization and embryo transfer (A case report). J Reprod Med 2000; 45: 754-7.

4. Lee CL, Wang CJ, Chao A, et al. Laparoscopic management of an ectopic pregnancy in a previous cesarean scar. Hum Reprod 1999; 14: 1234-6.

5. Maymon R, Halperin R, Mendlovic S, et al. Ectopic pregnancies caesarean section scars: the 8 year experience of one medical centre. Hum Reprod 2004; 19: 78-84.

6. Fylstra DL, Pound - Chang T, Miller MG, Cooper A, Miller KM. Ectopic pregnancy within a cesarean delivery scar: a case report, Am J Obstet Gynaecol 2001; 187: 302-4.

7. Huang KH, Lee CL, Wanf CJ, et al. Pregnancy in a previous cesarean section scar: case report. Changgeng Yi Xue Za Zhi 1998; 21: 3-327. 